\title{
KARATERISTIK WIRAUSAHA PENDATANG TERHADAP PERILAKU KEWIRAUSAHAAN MASYARAKAT LOKAL DI DESA SUKANAGALIH
}

\author{
Mulyaningrum \\ mulyaningrum@unpas.ac.id \\ Dewi Yuliati Indah \\ Fakultas Ekonomi dan Bisnis, Universitas Pasundan
}

diterima: 3/4/2019; direvisi: 22/6/2019; diterbitkan: 31/8/2019

\begin{abstract}
Cianjur Regency is one of the areas in West Java Province which is an alternative tourism development with a specific local culture. At present, there are many foreign tourists from Middle Eastern countries and many also settled in the area of Sukanagalih Village, Pacet District. As more tourists come to the district, economic activities grow much better as business opportunities for local people according to the market demand. However, there were also many migrants from the Middle East who participated in developing the business together with local communities. This study aims to analyze the influence of the characteristics of migrants from Middle Eastern countries on the business behavior of local communities in Sukanagalih Village. The method used in this study is descriptive and verification. Data collection was done using a questionnaire, supplemented by interviews and observations. The collected data is analyzed using linear regression, correlation, hypothesis test, and coefficient of determination.
\end{abstract}

Keywords: characteristics of entrepreneurship; behavior of entrepreneurial

\begin{abstract}
Abstrak
Kabupaten Cianjur merupakan salah satu daerah di Provinsi Jawa Barat yang menjadi alternatif pengembangan wisata dengan corak kebudayaan lokal yang spesifik. Pada saat ini banyak wisatawan asing dari negara-negara Timur Tengah yang akhirnya menetap di wilayah Desa Sukanagalih, Kecamatan Pacet. Dengan semakin banyaknya pendatang, maka tumbuh beberapa aktivitas ekonomi sebagai peluang usaha bagi masyarakat lokal sesuai permintaan pasarnya. Namun pada kelanjutannya banyak pula pendatang tersebut yang ikut mengembangkan usaha bersama-sama dengan masyarakat lokal. Penelitian ini bertujuan untuk menganalisis pengaruh karateristik pendatang dari negara-negara Timur Tengah terhadap perilaku usaha masyarakat lokal di Desa Sukanagalih. Metode yang digunakan dalam penelitian ini adalah deskriptif dan verifikatif. Pengumpulan data dilakukan dengan menggunakan kuesioner, dilengkapi dengan wawancara dan observasi. Data yang telah terkumpul di analisis menggunakan regresi linier, korelasi, uji hipotesis, dan koefisien determinasi.
\end{abstract}

Kata Kunci: karakteristik wirausaha; perilaku kewirausahaan 


\section{PENDAHULUAN}

Salah satu dampak adanya Masyarakat Ekonomi ASEAN (MEA) yaitu semakin mudahnya warga asing masuk ke Indonesia, dengan tujuan bisnis maupun menjadi wisatawan. Undang-Undang Nomor 9 Tahun 1990 tentang Pariwisata menyatakan bahwa pembangunan kepariwisataan sebagai bagian dari pembangunan nasional mempunyai tujuan antara lain memperluas dan memeratakan kesempatan berusaha, lapangan kerja, dan kesejahteraan rakyat. Dengan demikian pembangunan di bidang kepariwisataan mempunyai tujuan akhir untuk meningkatkan pendapatan yang berdampak pada peningkatan kesejahteraan masyarakat.

Peran pariwisata dalam pembangunan negara secara makro meliputi tiga segi yakni: (1) Segi ekonomis (sumber devisa, pajak-pajak); (2) Segi sosial (penciptaan lapangan kerja); (3) Segi kebudayaan (memperkenalkan kebudayaan kepada para wisatawan). Ketiga segi tersebut tidak saja berlaku bagi wisatawan asing, tetapi juga untuk wisatawan-wisatawan domestik yang kian meningkat peranannya (Spillane, 2013). Pada periode 2016, Passenger Exit Survey Departemen Budaya dan Pariwisata, menyatakan bahwa wisatawan asal negaranegara Timur Tengah telah membelanjakan uangnya di Indonesia sebesar 1.424,47 US\$. Dengan pengeluaran mereka tersebut telah memberikan kontribusi bagi perekonomian masyarakat Indonesia. Artinya, kehadiran wisatawan dari Timur Tengah telah memberikan dampak ekonomi yang positif bagi wilayah sekitar.

Sumber dari Dinas Budaya dan Pariwisata Kabupaten Bogor, perputaran uang di kawasan Puncak dan sekitar Kabupaten Cianjur, mampu mencapai angka triliunan rupiah setiap tahunnya, bahkan menjadi penyumbang PAD terbesar, 20 persen dari total PAD. Hal ini dapat dipandang sebagai penyumbang terjadinya pertumbuhan ekonomi yang luar biasa bagi masyarakat setempat. Begitupun pergerakan kegiatan bisnis dan wisata di wilayah Jawa Barat, tepatnya di desa Sukanagalih Kecamatan Pacet Kabupaten Cianjur.

Bertambahnya warga negara asing dari negaranegara Timur Tengah yang datang ke Desa Sukanagalih telah memberikan dampak pertumbuhan ekonomi yang cukup pesat. Hal ini dapat diukur dari kenaikan pendapatan masyarakatnya. Sebagai contoh, munculnya peluang usaha baru bagi masyarakat setempat, misalnya ternak kambing untuk memenuhi tingginya permintaan daging kambing sebagai hidangan khas warga asing dari negara Timur Tengah.

Aktivitas usaha kuliner di wilayah Desa Sukanagalih cukup menjanjikan, yang disebabkan oleh semakin banyaknya wisatawan asing dari Timur Tengah yang tinggal lama, bahkan menjadi penduduk permanen (permanent residents) di wilayah Desa Sukanagalih (Tabel 1).

Ada fenomena menarik dari pergerakan atau mobilitas masuknya warga negara asing di Desa
Sukanagalih, yaitu banyak ditemukannya perkawinan antar bangsa yang dilakukan melalui kawin kontrak (muth'ah). Pria asal negara Timur Tengah menikah dengan perempuan warga lokal, kemudian mereka mengembangkan usaha. Faktanya keadaan tersebut telah ikut andil dalam meningkatkan kesejahteraan ekonomi keluarga para perempuan lokal.

Pada kondisi sebelumnya, perempuan lokal harus bekerja keras untuk memenuhi kebutuhan ekonomi dengan terjun ke berbagai lapangan kerja dengan upah minimum atau sebagai pelaku usaha kecil saja. Namun pada belakangan terakhir ini dengan masuknya warga asing dari beberapa negara Timur Tengah, telah berdampak pada peningkatan pemenuhan kebutuhan hidup yang lebih layak dan lebih baik.

Pada saat ini wisatawan asing dari negara-negara Timur Tengah banyak yang bermukim dalam waktu relatif lama, dan menetap di wilayah Desa Sukanagalih, kemudian mereka mengembangkan usahanya. Warga negara asing tersebut ternyata memiliki perilaku dan karateristik kewirausahaan khas yang mendorong para pelaku usaha lokal untuk mengembangkan usahanya lebih baik. Hal ini karena pertaubuhan wisatawan asing menjadi pangsa pasar potensial untuk menggerakkan kegiatan ekonomi masyarakat. Keberadaan mereka bahkan menjadi tumpuan sumber pendapatan untuk meningkatkan kesejahteraan masyarakat lokal.

Kebudayaan merupakan ciri khas masyarakat satu dengan yang lain, yang terbentuk dari rangkaian proses adaptasi lingkungan dan evolusi budaya. Terjadinya akulturasi budaya antara warga asing dan warga lokal dipandang sebagai salah satu cara untuk meningkatkan kualitas kehidupan masing-masing. Hal ini dilakukan oleh penduduk lokal dalam kegiatan ekonomi sebagai peluang usaha, misalnya sebagai penyedia kebutuhan makanan, transportasi, dan tempat tinggal bagi wisatawan asing.

Menurut James J. Spillane (2013) bahwa produk pariwisata budaya memiliki segmen pasar khusus yaitu para "knowledge workers" atau dalam istilah kepariwisataan disebut "mature tourist" atau wisatawan yang berpengalaman. Wisatawan tersebut melakukan perjalanan atau kunjungan ke kawasan lain dengan tujuan tidak hanya bersifat recreational tetapi juga ada motivasi untuk menimba pengalaman melalui keterlibatan langsung dengan aktivitas kehidupan social dan tradisi serta budaya masyarakat lokal. Oleh karena itu, penelitian tentang bagaimana pengaruh karateristik pendatang dari negara Timur Tengah terhadap perilaku kewirausahaan masyarakat lokal di desa Sukanagalih Kecamatan Pacet Kabupaten Cianjur penting untuk dilaksanakan.

\section{METODE}

Metode penelitian yang digunakan dalam penelitian ini adalah metode deskriptif dan metode verifikatif. 
Metode deskriptif dilakukan dengan cara mengumpulkan, menyajikan serta menganalisis data sehingga memberikan gambaran yang cukup jelas atas obyek yang diteliti untuk dapat ditarik kesimpulan. Dalam penelitian ini metode deskriptif analisis digunakan untuk menjawab pertanyaan pada rumusan masalah sebagai berikut: (1) Bagaimana Karateristik wirausaha pendatang dari Timur Tengah di Desa Sukanagalih; (2) Bagaimana Perilaku kewirausahaan masyarakat lokal di Desa Sukanagalih.

Metode verifikatif menguji hipotesis dengan menggunakan perhitungan statistik. Dalam penelitian ini metode verifikatif digunakan untuk mengetahui besaran pengaruh karateristik wirausahaan pendatang dari Timur Tengah terhadap perilaku usaha pada masyarakat lokal di Desa Sukanagalih.

Penelitian ini dimulai dari penentuan variabelvariabel yang dibutuhkan lebih lanjut. Proses ini mencakup identifikasi variabel-variabel dan metoda pengukuran operasionalnya, penentuan populasi dan sampel yang akan diteliti, pengumpulan dan analisis data, serta menguji hipotesis.

\section{HASIL}

Karakteristik responden dilihat dari jenis kelamin, perimbangan jumlah responden dalam penelitian ini ada perbedaan; mereka yang berjenis kelamin laki-laki sebanyak 75 orang atau $75 \%$ dari total 100 responden sedangkan mereka yang berjenis kelamin perempuan sebanyak 25 orang atau mencapai $25 \%$. Ditilik dari usia, survey ini mencatat bahwa jumlah responden terbanyak adalah $36-46$ tahun, sebesar 35\%. Mereka yang sudah menikah tercatat sebanyak 90 orang $(90 \%)$, sedangkan sisanya 10 orang (10\%) belum menikah.

Responden yang menjadi subjek penelitian ini terbagi dalam beberapa kelompok Pendidikan, dan paling banyak SMA/SMK mencapai 55 orang $(55 \%)$, diikuti S1 berjumlah 20 orang (20\%), D3 sebesar 15 orang $(10 \%)$, sisanya SMP 10 orang $(10 \%)$ dan terakhir SD 5 orang (5\%). Berdasarkan lamanya berwirausaha ternyata mayoritas responden yang memiliki lama berwirausaha adalah antara $6-10$ tahun sebanyak 64 orang atau sebesar $64 \%$.

Berdasarkan hasil analisis tabulasi jenis usaha, mayoritas responden berusaha di bidang kuliner sebanyak 55 orang (55\%), selanjutnya jenis usaha budidaya sebanyak 30 orang atau sebesar $30 \%$, sisanya pada usaha kriya dan fashion. Hal ini mengindikasikan bahwa para pelaku wirausaha lebih dominan memilih jenis usaha kuliner karena banyaknya para pendatang khususnya dari Timur Tengah yang menjadi peluang usaha kuliner untuk memenuhi kebutuhan pokok mereka.

Karateristik kewirausahaan dalam penelitian ini diukur dengan 3 (tiga) dimensi yaitu: (1) Pengalaman, (2) Pengambilan risiko, dan (3) Inovasi. Dari ketiga dimensi ini terdapat 10 item pernyataan. Dimensi pertama, pengalaman, terdapat 4 (empat) item pernyataan yang terdiri dari: lamanya menjalankan usaha; mampu mengelola usaha; mampu menghadapi persaingan; dan mampu bekerja keras.

Dari indikator "lamanya menjalankan usaha" dapat diketahui bahwa responden mayoritas menyatakan setuju sebanyak 45 orang atau setara $45 \%$. Indikator "mampu mengelola usaha" mayoritas responden menyatakan setuju sebesar 54\%. Indikator "mampu menghadapi persaingan" mayoritas responden menyatakan setuju sebanyak $62 \%$. Indikator "mampu bekerja keras" diketahui bahwa responden mayoritas menyatakan setuju sebanyak 40 orang atau setara $40 \%$.

Dimensi kedua, pengambilan risiko, terdapat 3 (tiga) pernyataan yaitu: keberanian mengambil risiko usaha, mampu mengatasi kendala usaha, dan mampu mengambil keputusan dalam usaha. Dari indikator "keberanian mengambil risiko usaha", mayoritas responden menyatakan setuju sebanyak 35 orang (35\%). Indikator "mampu mengatasi kendala usaha", responden yang menyatakan setuju sebanyak 50 orang $(50 \%)$. Indikator "mengambil keputusan dalam usaha", responden menyatakan setuju sebanyak 55 orang $(55 \%)$.

Dimensi ketiga, inovatif, terdapat 3 (tiga) pernyataan yaitu: frekuensi melakukan perubahan dalam usaha, mampu mencari variasi produk, dan mampu menghasilkan ide baru. Indikator "frekuensi melakukan perubahan dalam usaha", responden yang menyatakan setuju 62 orang $(62 \%)$. Indikator "mampu mencari variasi produk", 53 orang (53\%) menyatakan setuju. Indikator "mampu menghasilkan ide baru', responden yang menyatakan setuju 45 orang (45\%).

Perilaku wirausaha masyarakat lokal dalam penelitian ini diukur dengan 3 (Tiga) dimensi yaitu: (1) Afektif, (2) Motorik, dan (3) Kognitif. Dari ketiga dimensi ini terdapat 10 pernyataan. Rekapitulasi tanggapan responden mengenai perilaku wirausaha adalah seperti pada Tabel 6 .

Dimensi pertama, afektif, terdapat 3 (tiga) pernyataan yaitu: dorongan menjalankan usaha dengan tekun, dorongan menjalankan usaha dengan gigih, dorongan menjalankan usaha dengan disiplin. Indikator "dorongan menjalankan usaha dengan tekun", responden yang menyatakan setuju 40 orang (40\%). Indikator "dorongan menjalankan usaha dengan gigih", 40\% responden mayoritas menyatakan setuju. Indikator "dorongan menjalankan usaha dengan disiplin", responden yang menyatakan setuju sebanyak 40 orang $(40 \%)$.

Dimensi kedua, motorik, terdapat 3 (tiga) pernyataan terdiri dari: keterampilan yang dimiliki pelaku usaha, mampu mengembangkan usaha, dan mampu menerima kritik. Indikator "keterampilan yang dimiliki pelaku usaha", responden mayoritas menyatakan setuju 50 orang $(50 \%)$. Indikator "mampu mengembangkan 
usaha" responden mayoritas menyatakan setuju sebanyak 52 orang (52\%). Indikator "mampu menerima kritik" responden mayoritas menyatakan setuju 45 orang $(45 \%)$.

Dimensi ketiga, kognitif, terdapat 4 (empat) pernyataan yaitu: orientasi meningkatkan usaha; mampu menyesuaikan pola pikir dalam menjalankan usaha; orientasi keberhasilan usaha; keyakinan mencapai target. Indikator "orientasi meningkatkan usaha" responden yang menyatakan setuju 48 orang (48\%). Indikator "orientasi meningkatkan usaha" responden mayoritas menyatakan setuju 48 orang (48\%). Indikator "orientasi keberhasilan usaha" diketahui responden yang menyatakan setuju 47 orang (47\%). Indikator "keyakinan mencapai target" responden mayoritas menyatakan setuju 45 orang (45\%).

\section{PEMBAHASAN}

Cianjur merupakan salah satu kabupaten di Provinsi Jawa Barat, yang dikenal dengan pameo ngaos, mamaos dan maenpo. Ngaos adalah tradisi mengaji sebagai salah satu pencerminan kegiatan keagamaan. Mamaos adalah pencerminan kehidupan budaya seni tembang Sunda Cianjuran berbibit buit (berasal) dari tatar Cianjur. Maenpo adalah seni beladiri tempo dulu asli Cianjur yang sekarang lebih dikenal dengan seni beladiri Pencak Silat.

Luas wilayah Kabupaten Cianjur $350.148 \mathrm{Km}^{2}$, dengan ciri topografi sebagian besar berupa daerah pegunungan, berbukit-bukit dan sebagian merupakan dataran rendah, dengan ketinggian 0-2.962 meter diatas permukaan laut (Puncak Gunung Gede). Kemiringan lahan 1\%-15\%. Lapangan pekerjaan utama penduduk di sektor pertanian yaitu sekitar 52\%. Sektor lainnya yang cukup banyak menyerap tenaga kerja adalah sektor perdagangan, $23,00 \%$. Sektor pertanian merupakan penyumbang terbesar terhadap PDRB Kabupaten Cianjur yaitu sekitar 42,80\% disusul sektor perdagangan sekitar $24,62 \%$.

Desa Sukanagalih berada pada wilayah Kecamatan Pacet Kabupaten Cianjur, termasuk destinasi wisata yang menarik bagi wisatawan domestic maupun asing. Daerah ini didominasi oleh tanaman sayuran, tanaman hias, dan bunga potong. Setiap hari belasan ton sayur mayur dan bunga potong dipasok ke wilayah Jakarta, Bogor, Tangerang, Depok, dan Bekasi (Jabotabek).

Sejak tahun 2016 sampai sekarang jumlah kunjungan wisatawan dari Timur Tengah semakin bertambah (Tabel 2). Hal ini menimbulkan fenomena meningkatnya penduduk perempuan yang melakukan praktik nikah kontrak dan nikah siri di Desa Sukanagalih (Puslitbang Kemenag RI, 2017). Hasil observasi menemukan bahwa praktik nikah kontrak dan nikah siri seolah menjadi sumber mata pencaharian dan menjadikan awal kegiatan bisnis seperti kuliner, seni pertunjukan, desain, ataupun fashion (Tabel 3).
Latar belakang pendidikan pelaku usaha mayoritas SMA/SMK, faktanya mereka dapat mengelola bisnis karena kegiatan wirausaha ini diawali dan berasal dari suami ke istrinya atau orang tua kepada anaknya yang kemudian juga menjadi wirausahawan, juga karena adanya kerabat dekat atau keluarga yang saat ini masih memiliki usaha masih didominasi oleh hubungan kekeluargaan yang dekat dapat memberikan nilai tambah yang positif bagi kegiatan wirausaha karena dapat menjadi faktor pendukung seperti finasial dan dukungan moril.

Berdasarkan hasil perhitungan rekapitulasi jawaban para pemilik dan pegawai menunjukan bahwa karatersitik kewirausahaan (Tabel 4) di Desa Sukanagalih masuk dalam kategori baik, hal ini dapat dilihat dari skor rata-rata yang dihasilkan dengan ratarata skor yaitu sebesar 369,8 berada pada interval 341420. Pernyataan dari tanggapan responden diatas ratarata kategori tertinggi yaitu pada dimensi pengalaman pada indikator mampu menghadapi persaingan dengan nilai skor 453, sedangkan terendah adalah pada dimensi pengambilan risiko usaha pada indikator keberanian mengambil risiko dengan nilai skor 303 . Hal ini dapat diartikan bahwa karateristik kewirausahaan di Desa Sukanagalih sudah baik, terutama dalam menghadapi persaingan usaha yang dijalankannya, akan tetapi dalam menghadapi risiko usaha masih belum dapat sepenuhnya di pahami bahwa dalam menjalankan usaha akan selalu diikuti konsekuensi dengan risikonya.

Karateristik kewirausahaan menurut Grave (2017) adalah sesuatu yang berhubungan dengan ciri khas, watak, perilaku, tabiat, serta sikap orang terhadap perjuangan hidup untuk mencapai tujuan bisnisnya. Dalam menjalankan usaha, pasti akan selalu terjadi perubahan pada situasi bisnisnya. Untuk itu sebagai seorang wirausaha harus memiliki sikap terhadap perubahan, sebagai bagian dari konsekuensi dan risiko bisnisnya (Clelland, 2016).

Hasil perhitungan rekapitulasi jawaban tanggapan para responden, sebagai pemilik usaha dan sebagai pegawai, pada variabel perilaku wirausaha menunjukan bahwa perilaku wirausaha dengan rata-rata skor yaitu sebesar 334,6 ada dalam interval $261-340$. Hal ini dapat diartikan bahwa secara umum perilaku wirausaha masyarakat Desa Sukanagalih masuk dalam kategori cukup baik (Tabel 5).

Perilaku kewirausahaan dipengaruhi oleh faktor internal dan eksternal. Faktor internal yaitu karakteristik orang yang bersangkutan yang bersifat given atau bawaan misalnya: tingkat kecerdasan, tingkat emosional, jenis kelamin, dan sebagainya. Faktor eksternal yaitu lingkungan, baik lingkungan fisik, fisik, ekonomi, politik, dan sebagainya (Notoatmodjo, 2017).

Pernyataan dari tanggapan responden dalam kategori tertinggi yaitu pada dimensi kognitif sebagai faktor internal, yaitu pada indikator "Keyakinan mencapai 
target" dengan nilai skor 388. Nilai terendah adalah pada dimensi afektif pada indikator menjalankan usaha dengan disiplin dengan nilai skor 294. Hal ini dapat diartikan bahwa perilaku wirausaha masyarakat di Desa Sukanagalih cukup baik, dalam keyakinan mencapai target usaha akan tetapi keyakinan tersebut belum sepenuhnya di sadari bahwa dalam menjalankan usaha perlu adanya sikap disiplin. Sebagai wirausahawan, harus memiliki sikap-sikap dasar yang spesifik sebagai prasyarat terbentuknya perilaku wirausaha (Sunaryo, 2014).

Pengujian terhadap 100 responden, pengaruh karateristik kewirausahaan terhadap perilaku wirausaha berpengaruh positif dan signifikan dengan nilai pengaruh sebesar 0,836 atau $83,6 \%$, maka dapat diartikan bahwa semkain tinggi karateristik kewirausahaan maka akan semakin tinggi perilaku wirausaha. Nilai R (koefisien korelasi) sebesar 0,836 berada diantara 0,80-1,00 yang berarti karateristik kewirausahaan memiliki tingkat hubungan yang kuat terhadap perilaku wirausaha. Hal ini sejalan dengan penelitian yang dilakukanoleh beberapa penelitian yang dilakukan oleh Dani Kartika (2018) pada penelitian "Hubungan karateristik dan perilaku wirausaha dengan kinerja usaha pedagang buah di pasar buah Brastagi Kabupaten Karo". Penelitian Kartika menemukan bahwa karakteristik wirausaha memiliki hubungan yang signifikan dengan perilaku wirausaha namun tidak memiliki hubungan dengan keterampilan. karakteristik wirausaha kepemimpinan memiliki hubungan yang signifikan dengan perilaku wirausaha sikap dan keterampilan, namun tidak memiliki hubungan dengan pengetahuan. Karakteristik wirausaha pedagang buah yang terdiri dari percaya diri, berani mengambil risiko, inovatif, kerja keras dan kepemimpinan memiliki hubungan yang signifikan dengan kinerja.

Tabel 1. Lama Tinggal Wisatawan Timur Tengah di Daerah Puncak dan Cianjur

\begin{tabular}{ccrcc}
\hline No & Tahun & \multicolumn{1}{c}{$<=1$ Bulan } & Sd 1 Th & Menetap Permanen \\
\hline 1 & 2015 & 50.000 Orang & 800.000 Orang & 650.000 Orang \\
2 & 2016 & 4.600 .000 Orang & 500.000 Orang & 300.000 Orang \\
3 & 2017 & 5.000 .000 Orang & 700.000 Orang & 300.000 Orang \\
\hline
\end{tabular}

Sumber: Dinas Wisata dan Budaya Kabupaten Bogor

Tabel 2. Data Kunjungan Wisatawan Timur Tengah ke Puncak

\begin{tabular}{ccc}
\hline No & Tahun Kunjungan & Jumlah Orang (dalam Juta Jiwa) \\
\hline 1 & 2015 & 1.5 \\
2 & 2016 & 5.4 \\
3 & 2017 & 6 \\
\hline
\end{tabular}

Sumber: Dinas Wisata dan Budaya Kabupaten Bogor

\section{KESIMPULAN}

Berdasarkan hasil penelitian dapat diambil kesimpulan sebagai berikut: (1) Karateristik kewirausahaan di Desa Sukanagalih sudah baik, terutama dalam menghadapi persaingan usaha yang dijalankannya; tetapi dalam menghadapi risiko usaha masih belum dapat sepenuhnya di sadari bahwa dalam menjalankan usaha akan selalu diikuti konsekuensi dan risikonya; (2) Perilaku wirausaha di Desa Sukanagalih cukup baik, dalam keyakinan mencapai target usaha akan tetapi keyakinan tersebut belum sepenuhnya di sadari bahwa dalam menjalankan usaha perlu adanya sikap disiplin; (3) Pengaruh karateristik kewirausahaan terhadap perilaku wirausaha adalah positif dan signifikan dengan nilai sebesar $83,6 \%$. Artinya, semakin tinggi karateristik kewirausahaan maka akan semakin tinggi perilaku wirausaha.

\section{DAFTAR PUSTAKA}

Clelland Mc David. 2016. The Achieving Society. New Jersey: Prentice-Hall.

Dani Kartika 2018. Hubungan Karateristik Dan Perilaku Wirausaha Dengan Kinerja Usaha Pedagang Buah Di Pasar Berastagi Kabupaten Karo. IPB.

Grave.Alih Bahasa Dedi 2017. Kewirausahaan. Wijaya Mahardi Karya. Yogyakarta.

Notoatmojo. 2017 dalam Novita Dayu 2019. Pengaruh Motivasi Dan Pengetahuan Kewirausahaan Terhadap Kesiapan Berwirausaha. Jurnal Administrasi Bisnis Unmul Vol.7 No.1 Hal. 51-63.

Sunaryo. 2014. Potensi Kepribadian Wirausaha dan Pengetahuan Kewirausahaan Jurnal Pendidikan Vokasi, Vol 2, Nomor 3.

Spilane. Alih Bahasa Karisma 2013. Pariwisata Indonesia Dan Prospeknya. Yogyakarta.

Tabel 3. Jumlah Pengusaha Kuliner Menurut Skala Usaha di Desa Sukanagalih (Dalam Satuan Unit Usaha)

\begin{tabular}{llcc}
\hline No & Jenis Usaha & Tahun 2016 & Tahun 2017 \\
\hline 1 & Mikro & 605 & 649 \\
2 & Kecil & 94 & 105 \\
3 & Menengah & 46 & 59 \\
\hline & Total & 476 & 813 \\
\hline
\end{tabular}

Sumber: Data Desa Sukanagalih, diolah 2017 
Tabel 4. Rekapitulasi Jawaban Mengenai Karakteristik Kewirausahaan

\begin{tabular}{|c|c|c|c|}
\hline No & Item & Jumlah & Rata-rata \\
\hline & Dimensi: Pengalaman & & \\
\hline 1 & Lamanya Menjalankan Usaha & 325 & 65 \\
\hline 2 & Mampu Mengelola Usaha & 347 & 69.4 \\
\hline 3 & Mampu Menghadapi Persaingan & 453 & 90.6 \\
\hline \multirow[t]{2}{*}{4} & Mampu Bekerja Keras & 314 & 62.8 \\
\hline & Dimensi: Pengambilan Risiko & & \\
\hline 5 & Keberanian Mengambil Risiko & 303 & 60.6 \\
\hline 6 & Mampu Mengatasi Kendala Usaha & 388 & 77.6 \\
\hline \multirow[t]{2}{*}{7} & $\begin{array}{l}\text { Mampu Mengambil Keputusan } \\
\text { Dalam Usaha }\end{array}$ & 405 & 81 \\
\hline & Dimensi: Inovatif & & \\
\hline 8 & $\begin{array}{l}\text { Frekuensi Melakukan Perubahan } \\
\text { Dalam Usaha }\end{array}$ & 372 & 74.4 \\
\hline 9 & Mampu Mencari Variasi Produk & 406 & 81.2 \\
\hline \multirow[t]{2}{*}{10} & Mampu Menghasilkan Ide Baru & 385 & 77 \\
\hline & Rata-rata & 369.8 & \\
\hline
\end{tabular}

Tabel 5. Rekapitulasi Jawaban Mengenai Perilaku Wirausaha Masyarakat Lokal

\begin{tabular}{llcc}
\hline No & \multicolumn{1}{c}{ Item } & Jumlah & Rata-rata \\
\hline & Dimensi: Afektif & & \\
\hline 1 & Menjalankan Usaha dengan Tekun & 330 & 66 \\
2 & Menjalankan Usaha dengan Gigih & 310 & 62 \\
3 & Menjalankan Usaha dengan Disiplin & 294 & 58.8 \\
\hline \multicolumn{2}{l}{ Dimensi: Motorik } & & \\
\hline 4 & Keterampilan yang dimiliki Pelaku Usaha & 335 & 67 \\
5 & Mampu Mengembangkan Usaha & 337 & 67.4 \\
6 & Mampu Menerima Kritik & 330 & 66 \\
\hline \multicolumn{2}{l}{ Dimensi: Kognitif } & & \\
\hline 7 & Orientasi Meningkatkan Usaha & 361 & 72.2 \\
8 & Mampu Menyesuaikan Pola Pikir dalam & 319 & 63.8 \\
& Menjalankan Usaha & & \\
9 & Orientasi Keberhasilan Usaha & 342 & 68.4 \\
10 & Keyakinan Mencapai Target & 388 & 77.6 \\
\hline & Rata-rata & 334.6 & \\
\hline Sumber: Hasil olah data 2018
\end{tabular}

Sumber: Hasil olah data 2018 